\title{
HUSSERL AND THE FACT OF PRACTICAL REASON - PHENOMENOLOGICAL CLAIMS TOWARD A PHILOSOPHICAL ETHICS*
}

\author{
Sophie Loidolt \\ Department of Philosophy, University of Vienna, \\ Universitätsstraße 7, A-1010 Vienna, Austria \\ E-mail: Sophie.Loidolt@univie.ac.at
}

The thesis of this paper is that Husserl, in his later ethics, reinterprets the philosophical content that discloses itself in the Kantian conception of a "fact of practical reason". From 1917/18 on, Husserl increasingly ceases to pursue his initial idea of a scientific ethics. The reason for this move lies precisely in the phenomenological analysis of "Gemütsakte", through which two main features of the fact of practical reason impose themselves more and more on Husserls thought: the personal concernment/obligation and the primacy of the practical with the coeval call for universal validity.

Husserl recognizes that the form of ethical facticity or entanglement cannot be grasped by a science of evidence, which speaks objectively and non-personally (apersonal) of acts of willing, valuing or preferring. Husserl thus gets to a reinterpretation of the fact of practical reason as the philosophical nucleus of his ethics, which is now a personal and affective ethics. He bestows a texture on this fact, however not as he would have thought in the first place: not as evident laws of a material apriori of "Gemüt". In the person and her ethical experience as absolute affection Husserl rather discovers that which is per se not objectifiable and not to be made rationally evident. By this, Husserl captures and phenomenologically explains the non-objectifiable source of obligation and the possibility of complying with it.

Keywords: phenomenology, Husserl, Kant, ethics, practical reason.

DOI: $10.3846 / 1822-430 X .2009 .17 .3 .50-61$

\section{Introduction: The fact of practical reason as a philosophical problem}

The title of this paper: "Husserl and the Fact of Practical Reason" seems to place Husserl in a direct relation to Kant, whose ethics - as is well known - contains the argument which appeals to the fact of practical reason' (FPR). To avoid any misunderstandings, which could arise from this title, I would like to make clear from the very outset that it is not my aim to present Husserl as a direct follower of Kant (even if my interpretation of Husserlian ethics is more Kantian than Aristotelian) and can neither address the influences of Fichte nor Brentano).

\footnotetext{
* This paper is the English translation of the talk "Husserl und das Faktum der praktischen Vernunft - Phänomenologische Ansprüche an eine philosophische Ethik", that I gave at the conference "Phenomenology - Science Philosophy" of the Husserl-Archives in Leuven 2009. It will be published in the conference papers in German in the Phaenomenologica-Series in 2010. I would like to thank Niall Keane for his helpful comments concerning the English translation of the text.
} 
Instead, what makes this constellation interesting to me is - on the one hand - the philosophical problem of ethical experience that crystallizes in the thesis of a FPR and that Husserl gets drawn to this argument the more he deepens his ethical reflections; on the other hand I am interested in how Husserl confronts this problem with his phenomenological claims and how this enables him to break new ground. This special philosophical and phenomenological constellation can thus lead us to a new and fruitful interpretation of how we can understand 'practical reason' as well as the givenness of its facticity. This implies a phenomenological reading of Kant that I will try to put forward in the following.

Let me clarify first how I would like to understand the thesis concerning the "fact of practical reason" (FPR): In this thesis we can find the condensed content of Kantian ethics as it intends to give an answer to three basic questions:

1. The question concerning the source of ethical obligation and the manner of its givenness (Answer: as moral law, but even more essential: as a factually experienced imperative through the feeling of respect).

2. The question concerning the possibility of obeying the experienced obligation (Answer: through freedom, or better: as practical freedom which includes the primacy of the practical insofar as freedom is theoretically unrecognizable).

3. The question concerning how (in which manner) I can obey the experienced obligation (Answer: through the categorical imperative; what Rawls calls the "CI-Procedure" (Rawls 1993: 291ff.)).

The crucial point is that Kant wants to show that questions 1 and 2 - the ethical claim and the source of its obligation - cannot be deduced or constructed, but are given to us directly in the form of a claim/demand. Kant himself speaks almost 'phenomenologically' in this case:

"Man kann das Bewußtsein dieses Grundgesetzes ein Faktum der Vernunft nennen, weil man es nicht aus vorhergehenden Datis der Vernunft [...] herausvernünfteln kann, sondern weil es für sich selbst uns aufdringt als synthetischer Satz a priori [...]. Doch muß man, um dieses Gesetz ohne Mißdeutung als gegeben anzusehen, wohl bemerken: daß es kein empirisches, sondern das einzige Faktum der reinen Vernunft sei, die sich dadurch als ursprünglich gesetzgebend (sic volo, sic iubeo) ankündigt" (KpV, Erster Teil, Erstes Buch, Erstes Hauptstück, \$7: 55f.).

It shall not be of greater interest here with what kind of theoretical presuppositions Kant tries to back up this givenness of practical reason (e.g. the "two-world-interpretation"), but that he understands the ethical primarily from an irreducible/ineluctable (unhintergehbar) and factual experience of an appeal (Anspruch) ${ }^{1}$. This appeal directly 'hits' us, however, in the form of the law, i.e. in the imperative demand for universal validity. For Kant, this form of absolute and universal validity of moral principles is indispensable, as only universally valid morals can be binding morals. Thus the importance of point 3 , i.e. the rule of application by means of the categorical imperative that should provide a sufficient and adequate answer to the question: "What ought I to do?"

Already in his first approach to ethics, Husserl does not at all agree with Kant in how he tries to solve the question of point three, namely through the strict separation of sensibility and reason. Husserl's objections rely on the phenomenological method. What he criticizes in Kant is the lack of a pathic/emotive (gemütsmäßige) texture of

1 The German term 'Anspruch' combines several semantic levels which can be translated with the English terms 'claim' or 'appeal': 'claim' rather emphasizes the juridical and normative component while 'appeal' stands for the prepredicative, experiential feature which foregoes its predicative transformation into a certain normative claim. Thus, I will use the expression 'appeal' whenever this prepredicative aspect comes into play (in this context, another term I will use is 'call' (Ruf)). 
the willing, as if one could speak of a tone without a quality (of tone) and of a color without expansion. According to this critique, Husserl is looking for a priori universal and ideal laws in emotive and volitional acts (Gemütsakte) that accompany the ethical will.

In the first version of his ethics (Hua XXVIII: Vorlesungen über Ethik und Wertlehre 1908-1914) Husserl thus aims for a scientific eth$i c s$, which should provide evidence concerning the whole issue of ethics (formal and material), by established phenomenological means. What I would like to show in this paper is, however, that Husserl increasingly ceases to pursue this idea of a scientific ethics. The reason for this move lies precisely in the phenomenological analysis of Gemütsakte, through which the first two features of the FPR impose themselves more and more on Husserls thought: the personal concernment/obligation and the primacy of the practical with the coeval call for universal validity.

Husserl recognizes that this form of ethical facticity or entanglement cannot be grasped by a science of evidence, which speaks objectively and non-personally (apersonal) of acts of willing, valuing or preferring. In my view, Husserl thus gets to a reinterpretation of the FPR as the philosophical nucleus of his ethics, which is now a personal ethics. He bestows a texture on this fact, however not as he would have thought in the first place: not as evident laws of a material apriori of Gemüt. In the person and her ethical experience as absolute affection Husserl rather discovers that which is per se not objectifiable and not to be made rationally evident.

My additional thesis is that Husserl's turn is not something irreproducible or something like a leap, but that the very analysis of experience and the evidence-problem in the field of the practical lead him to this conclusion. My paper will thus be structured in the three following parts: 2. Husserl's phenomenological conception of a scientific ethics, 3. Husserl's later ethics, 4. Husserl's FPR in the dimensions of the affective and the personal.

\section{Husserl's phenomenological conception of a scientific ethics}

In his initial approach to ethics Husserl tries to solve the antitheses between Hume's ethical sensualism and Kant's ethical absolutism by subjecting both the formal and the material sphere to a comprehensive phenomenological analysis of the acts of feeling and willing (Gemütsakte). Following a strong parallelism to logic where Husserl had already accomplished remarkable things, he also divides the field of ethics into formal and material a priori (and a posteriori): The a priori part of ethics consists of the elaboration of a formal axiology and formal praxis (Praktik) (containing laws of comparison and ranking of values as well as volitional laws of consequence), and a material axiology which determines the content of the ought (Cf. Hua XVII: $3-157)^{2}$. The act of willing is situational and thus to be determined a posteriori. Husserl's Brentano-inspired reworking of the categorical imperative thus reads: Do the best that is attainable! (Hua XVIII: 153).

In this outline of a scientific ethics one can find remarkable advantages that primarily concern the formal dignity of Gemütsakte for an ethical conception. However, Husserl has to face new problems with his strategy that I can only briefly touch upon: A. The unclear benefit or status of axiological and practical reason and B. the unclear status of valuing (Wertnehmen) and the non-person-oriented anonymity of an ethics of the highest good.

ad A: Values are given to us in acts of feeling and willing (Gemütsakten), evaluative and volitional reason are - according to Husserl "mute" and "blind" (Hua XXVIII: 68). This corresponds to Husserl's conception of different forms of reason according to different classes of acts: there are intellective acts (i.e. acts of presenting and thinking), acts of feeling (emotive acts) and acts of willing (volitional acts). The

${ }^{2}$ For a closer examination of the structure and main arguments of Husserl's early ethics cf. Melle 1998, 2005a, 2005b, Drummond 2005, Crowell 2005. 
three corresponding forms of reason are: theoretical, axiological and practical reason. These three forms possess different features. Since all Gemütsakte (emotive and volitional acts) in Husserl's conception are non-objectifying acts, i.e. they do not give an object as object, their corresponding forms of reason cannot directly give objects or objectivity and thus no evident positings. In order to accomplish this, they are dependent on intellective, objectifying acts, ergo theoretical reason which - according to Husserl - illuminates (hineinleuchten) the dark non-objectified spheres of evaluative reason with its "logical torch" and transforms this somehow available form of rightful evaluation into the form of valid predication (cf. Hua XVIII: 68-69). One can see, that the concept of an intuitively fulfilling evidence and its corresponding notion of reason has its difficulties when applied to a sphere that is conceptualized as being "blind". Nevertheless Husserl holds on to this difficult conception in a certain way. It nearly seems as if Husserl - as paradoxical as it may sound - delineates something like a 'prepredicative' reason, which has yet to be brought into the form of predication. When I struggled with this problem in my dissertation I chose one of the several proposals for solution that Husserl tries out in his struggle with the problem, namely that path which concentrates on the model of the prepredicative/evaluative and predicative/theoretical (cf. Loidolt 2009: $181-191)^{3}$. This seemed phenomenologically plausible to me, as it neither undermines the

\footnotetext{
${ }^{3}$ In my dissertation Anspruch und Rechtfertigung I have tried to develop a phenomenological theory of judgments on legitimacy. i.e. a first systematic investigation of the structures in consciousness which enable the process of justification to unfold. The overall question was how the claim for legitimacy, inherent to both epistemological and ethical judgements, can be understood as a fundamental characteristic of experience. My thesis gives a genetic answer to this question. It traces the characteristic of legitimation back to an originary appeal consciousness is exposed to by experience. Legitimizing structures are thus to be understood as a predicative answer to this prepredictaive appeal.
}

givenness of valuing on the one hand, nor, on the other hand, disregards the deliberative moments, that are always involved in our ethical decision-making and validity-claims (Rechtsfragen). (These deliberative moments can also take place intuitively, e.g. in eidetic variation). By deliberation I try to pinpoint conceptually that which is given to me emotively by/ in valuing: I vary it, either as a impartial/ non-participating observer (that Husserl often refers to) or "as if I was there" or within the categorical imperative - and this is how I attain my predication of validity/legitimacy. All these are operations that I can only perform with the help of objectifying, theoretical reason, even if I am reliant on the genuine givenness of 'value' within prepredicative axiological reason.

But this is only one byway which Husserl points to (cf. Hua XVIII: 370) and which I have chosen, but not his main approach. Husserl wants to keep the different classes of acts strictly separated, in their own qualities and in their own forms of activity and passivity. Still the question remains how the legitimacy of my judgments out of my personal acts of pleasure and displeasure is actually given, and what the 'logical torch' really sheds its light on?

ad B: The unclear status of valuing. Husserl conceptualizes the act of valuing as an analog to the act of perception - however this is a problematic use of analogy, (since perception gives an object and valuing does not per definitionem). In these acts of valuing, emotions are supposed to be founded distinctively on other distinct objective perceptions (objective content), and these emotions are expected to open up the sphere of values as quasi-objects in an unambiguous, clear and quasi-objective way. I cannot cover all those questions that arise in connection with this method ${ }^{4}$. One of the main conceptual problems with this valueobjectively-on-object-intuition seems to me

\footnotetext{
${ }^{4}$ For a closer examination cf. Schuhmann 1991, Crowell 2005 and Drummond 2005.
} 
that Husserl aims at a pure and evident valuing of a pure consciousness, like in the theoretical realm. But this not only undermines the a posteriori situation, in which the acting person finds herself; it contradicts the apriori situatedness (Situativität) of feeling and valuing as a personal act of a psychophysical being - the human being.

Insofar as Husserl develops his ethics as a personal ethics and since the person is not even imaginable without her environment (Umwelt) (Hua IV: 185-190) the acts of feeling and valuing are in fact developed as something 'practical' and situational and not as a distanced act of universal and pure intuition. Hence, it seems to me that Husserl's insight during the 20s, concerning the "absolute Willensrichtigkeit" and the "highest practical good", also holds true for valuing (Wertnehmen): evaluative and volitional laws that are totally independent of the personal, quasi non-interested preference-laws, which could be "recalculated" by anybody, are simply implausible:

"So ist die Brentanosche Regel unzureichend. Jeder hat sein absolutes Sollen, und seine Wahl vollzieht sich in der Frage, was soll ich, und wo ich mehreres soll, welches ist jetzt mein Notwendiges - nicht einfach, welches ist das in der Gütervergleichung Bessere. [...] Alle praktischen Güter stehen für mich nicht in einer Ebene, auch nicht alle, die ich verwirklichen könnte. Die Stimme des Gewissens, des absoluten Sollens, kann von mir etwas fordern, was ich keineswegs als das in der Wertvergleichung Beste erkennen würde“ (Hua XXVIII: XLVII).

"Diese ganze Ethik des höchsten praktischen Gutes, so wie sie von Brentano abgeleitet wurde und von mir in wesentlichen Zügen angenommen, kann nicht das letzte Wort sein. Es bedarf wesentlicher Begrenzungen! Beruf und innerer Ruf kommen dabei nicht zu ihrem wirklichen Recht" (Hua XXVIII: XLVIII, footnote 1)

- which brings the focus to the non-personoriented anonymity of an ethics of the highest good. Husserl increasingly recognizes this deficiency. I would like to explain this thought with the following thesis: It becomes precisely clear in a science of Gemütsakte, that their material a priori cannot be the correlate of a pure, non-situational gaze (or act of valuing). In fact, the a priori situatedness of the person has to be included into the material a priori of valuing and willing. This not only demands that we reformulate the question of 'reason'. It forces us to admit that a method, which aims at a non-situated Wertwahrnehmung, fails to grasp the genuine ethical concernment/consternation/pathos (Betroffenheit) that shows itself in a phenomenological analysis of ethical experience. The missing texture, which Husserl rightly reproaches Kant for having overlooked, cannot be captured in Husserl's scientific ethics either, at least not in its ethical drive/force, but only as a sort of - questionable - 'emotive cognition' (Gefühlserkenntnis). The actual affective texture of ethical experience is, however, not an objectifiable material a priori that appears in apodictic evidence, but this texture is personal and thus ultimately non-objectifiable. In pursuing this character of the a priori situatedness of the person, Husserl attempts to reformulate the FPR in terms of a personal vocation (Gerufen-Sein).

\section{Husserl's later ethics}

Husserl's second, transformed conception of ethics, which he develops in the 20s, exhibits one side that stresses the rational aspect (Husserl publishes this approach in the form of the Kaizo-Articles 1923/24, Hua XXVII) and another side that stresses the affective aspect (this approach can only be found in the unpublished manuscripts; approximately beginning from 1917/18 when Husserl also becomes interested in passive synthesis).

\section{A. Renewal (Erneuerung)}

Let me discuss the rationalist aspects first, which can also be summed up under the title 
of an "ethics of renewal and self-preservation/ self-determination (Selbsterhaltung)". Central to this idea is a self-ruling, legitimizing attitude (Haltung), which stretches out over a whole life by a free decision. It remains in permanent striving for renewal according to the claim of reason. With it, the will comes to the fore as a universal and at the same time individual force of intentional life - and consequently the primacy of the practical is installed. The practical dimension of reason, that is the willing, overlies the theoretical dimension - and not only in the ethical sphere, but in a parallel move also in the epistemological realm where Husserl speaks of intentionality as a striving or willing for knowledge (in Experience and Judgment: EU 235ff).

In the course of these alterations, Husserl's formulation of the categorical imperative also changes: "Sei ein wahrer Mensch; führe ein Leben, das du durchgängig einsichtig rechtfertigen kannst, ein Leben aus praktischer Vernunft.“ (Hua XXVII: 36).

What does practical reason now mean in this context? We are dealing with a will, that is still conceptualized in a very formal way and that is meant to extend over a whole life in order to become an "ethically responsible/mature (mündig) human being” (Hua XXVII: 43). In the beginning I mentioned freedom and autonomy as two main features that we recognize in the givenness of the FPR (ratio cognoscendi); this aspect must come into play here to tie in with Husserl.

As for Husserl, however, this experience that leads to the cognition of freedom is initially not an experience of coercion by the law (the universal validity-claim), but rather the experience of an "I can" (ich kann). The "universal self-reflection (Selbstbesinnung)" and the "decisive determination" that Husserl appeals for, is a "free Urstiftung or Urzeugung" (Hua XXVII: 43) that results from the force of my transcendental life. In this respect, it is not the consciousness of the law that "derogates my self-love (meiner Selbstliebe Abbruch tut)" (Kant, Grundlegung, BA 17) and thus calls on me to become autonomous by the means of this heteronomous experience. The original motive to pass from mere affectivity onto free deliberation, is similar, however, still very different: I don't get into the painful but uplifting self-contradiction between universal reason and subjective inclination (Neigung). Rather I get into the self-contradiction of disappointment and doubt: It turns out that the values which I perceived to be right are in fact wrong, which means the conduct of my entire life is at stake. What we can clearly recognize here is the different conception of reason in Kant and in Husserl: While for Kant, the law or the structure of lawfulness constitutes the structure of validity, for Husserl it is the originary intuitively fulfilled evidence that guarantees validity; while a subjective inclination (Neigung) for Kant can conceptually never gain or found validity, for Husserl it is a time-process where my doxic positings can turn out to be wrong.

Only that Husserl does not say any more about the evidence of values (Wertevidenz) or axiological reason in the Essays on Renewal (Hua XVII). He rather shifts his emphasis thoroughly to the (formal) will, i.e. to practical reason combined with justification/legitimization out of theoretical reason. Man as a rational being, striving for absolute justification is "das ins Unendliche werdende Werk, dessen Werkmeister er zugleich ist" (Hua XXVII: 37); s/he lives the true humane life as a life of "method" toward the ideal humanity (cf. Hua XXVII: 38); s/he "is" not the person as a sum of quasi-objective properties but s/he is "becoming it" by acting it out (im Sich-Vollziehen) through an ever-renewing decision. However: the texture of this personality, what makes her this unique ethical person, is missing in the Husserlian text on renewal. In this respect, there remains a conceptual gap, as the Husserlian ethical subject is different to the Kantian ethical subject: It does not experience its freedom in the call for the universal. It rather lives a concrete ethical blueprint or design (Entwurf), in which the step to universality is actually the product of 
a concurrent, varying "I can". The 'call' - insofar as it is the nucleus of the FPR - occurs differently: Disappointment, which has been pointed out before as a motivating reason, is at most its negative image, its risk, that which renewal and justification try to attenuate by rational means: Because the 'call' that reaches the Husserlian ethical subject, is not universality but "absolute affection".

In this respect, the "continuously insightful justification" that Husserl demands in his new formulation of the categorical imperative, becomes a problem. Because with the concept of 'absolute affection', Husserl's conception of the person deepens significantly and hence the difficulties with the evidence of Gemütsvernunft emerge again.

\section{B. Ethics of 'absolute affection'}

The thesis I mentioned at the beginning: that Husserl attains a new formulation and thus a new, affectively elaborated interpretation of the FPR, shall now be fleshed out. Husserl reformulates both the facticity and the experience of being called (Ansprüchlichkeit) that occurs in ethical experience. Hence, Husserl broadens the approach from a still existentially experienced, however, merely formal claim for universal validity in Kant, toward a personal, affective and thus concrete concern (Betroffenheit).

To begin with, one can see a modification in the ontology of the personal subject from 1917/18 (Melle 2004: 348):

"Ein Besonderes ist es aber, dass das Ich nicht nur polare, zentrierende Innerlichkeit ist, dabei aus sich Sinn und Wert und Tat leistende Innerlichkeit, sondern dass es auch individuelles Ich ist, das [...] ein tiefstes Zentrum hat, das Zentrum jener Liebe im ausgezeichneten personalen Sinne, das Ich, das in dieser Liebe einem 'Ruf', einer 'Berufung' folgt, einem innersten Ruf, der die tiefste Innerlichkeit, das innerste Zentrum das Ich selbst trifft und zu neuartigen Entscheidungen, zu neuartigen ,Selbstverantwortungen', Selbstrechtfertigungen wird.“ (Husserl, Ms. B I 21: 56a).
In this and other quotations, one can read about Getroffenheit, Affektion, the awakening of the deepest ego; not only the vocabulary of the passive sphere, also its irrefutable affective force is declared 'central' to the ethical person. The notion of love that appears simultaneously, seems to characterize the loving act of following or responding to an irrefutable, affective, ethical call. In this context, the notion of freedom also receives a new connotation/meaning: The subject's freedom now expresses itself in either following the call or in not listening to the call or refusing the response. The ethical subject thus constitutes itself as a free responding subject; the self dedicates itself actively and willingly to the unconditional service of the awakening call, and this even beyond universal reason (Melle 2004: 348). It is only through that move, that it becomes this very person that ought to follow this very value. It is only through that move, that values originate at all, and become 'absolute' within this individual response.

Thus, also the conception of value changes substantially from an evidently conceivable value to a value that only emerges within the act of loving appreciation/esteem (Wertschätzung): "Liebeswert ist nur das, was sich im liebend-sorgenden Tun, immer in der Schwebe zwischen gelungenem und misslungenem verwirklicht" (Husserl, Ms. A V 21: 83a).

With these formulations, Husserl indeed succeeds in coining a non-objectified valueconcept and thus a concept of axiological reason, which is rather understood by the way it is performed (Vollzug) than by its knowledgefactor. Because of the initially enigmatic and irritating non-objectifying component of practical and axiological reason, Husserl hits on an essential feature of ethical experience: namely that we are being called by an ought, a call, which never becomes a complete 'object' for our perception. A theoretical and objectifying attitude can never fully meet the demands of this imperative; a distanced view/consideration is not possible anymore; rather the subject is directly affected/concerned and called to take over itself (sich übernehmen). 
The "absolute of the personality" is even constituted by the "absolute demands of the ought" (Sollensforderungen); the subject is actually bound and individuated in this affective being-called (Angesprochen-Sein). It cannot deny it without doing "crucial damage" (Husserl, Ms. A V 21: 117b) to itself - and all this takes place prior to a rational demand for evidence:

"Es gibt ein unbedingtes 'Du sollst und mußt, das sich an die Person wendet und das für den, der diese absolute Affektion erfährt, einer rationalen Begründung nicht unterliegt und in der rechtmäßigen Bindung von ihr nicht abhängig ist. Diese geht aller rationalen Auseinandersetzung, selbst wo sie möglich ist, vorher." (Hua XXVIII, XLVIII, Anmerkung 1).

In comparison to the ethics of renewal where Husserl talks about "continuous insightful justification", the quotation above indeed sounds very different. Nevertheless, judgment remains necessary; nevertheless, there is no such thing as taking leave of the 'rational' by Husserl, that which theoretical, demonstrative and justifying/legitimizing reason stands for.

\section{Husserl's Fact of Practical Reason in the dimensions of the affective and the personal}

My thesis was that Husserl reinterprets the philosophical content that discloses itself in the conception of a FPR, with the help of his phenomenological method. That is to say, he interprets it in personal and affective terms. Husserl thus attempts to give the Kantian subject of reason an affective texture, however, not only in the sense that the component of Gemüt merely provides another and different function of cognition for questions of ethical decision-making; rather in being itself the event/performance of the ethical (indem es selbst das Ereignis des Ethischen vollzieht). Husserl, in his later ethics, thus tries to describe the experience of the ought as an individual respectively ethical becoming of person, whose affections are not only pathic/ pathological (Kant) or self-centered/egoistic; he tries to phenomenologically describe the ethical call - which functions just the same as the call for the universal (in Kant) in tearing the self out of its ego-logic, out of its self-sufficiency of the mere pleasure-principle.

By this, Husserl captures and phenomenologically explains the non-objectifiable source of obligation and the possibility of complying with it. In Kant's conception, one could say, that I am being called to universal freedom through the experience of the law; in Husserl's conception, I am called to my very concrete freedom through absolute affection. While the possibility to be free in general is accompanied by the feeling of respect, the concrete freedom in respect of something is accompanied by the feeling of love.

Of course Kant leaves us with difficulties (to a lesser extent with the thesis of a FPR than with the CI-procedure), whose existence he mostly utterly denies: there are various possibilities of interpreting the categorical imperative; there are many different varieties of interpretations that can all seem universalizable/generalizable with respect to a necessary ethical decision. One can solve this problem within the concept of communicative reason like Habermas, or one can choose a more existentialist interpretation of Kant: which means that I have to vouch and answer for my decision. The thesis of a FPR in Kant does not however provide any reference to this. Only in Husserl's interpretation does the facticity of the ethical call/claim distinctively get this dimension. Because in his interpretation, there is not only a FPR that emerges as the law but also - simultaneously - as a fact of the person who is heteronomously determined in its foundations. However, this fact of the person is never 'pathological' in Kant's sense, but ethical, as it breaks into my merely subjective inclinations, tears me out of my mere selfish living and makes a formative will possible, which is heteronomously founded, but yet a responding freedom. 
One could thus claim that the FPR in Kant remains under-determined as it only covers the call for formal universality; one could also claim that Husserl completes this description; in his second attempt he succeeds in grasping the personal concern for the ethical as well as succeeding to elaborate its affective texture, in which vocation and personal calling are done justice to.

But does not the very character of reason drop away with this move? Isn't it precisely in this affective interpretation of the fact of practical reason that we lose what is considered the fact of practical reason? Husserl seems to take this point of view; however, the question is, if Husserl - at this point - is not falling back into an understanding of reason which is thoroughly determined by a theoretical and 'rationalist' gesture. (In the following I do not equate reason and especially not the givenness of reason with 'ratio'.)

In order to discuss this question, let me bring to mind the different forms in which reason appears in Husserl's later ethics:

1. as theoretical reason that is still responsible and competent for justification and science (Wissenschaft); however, it now also acts as reason ex post which obtains a new source of self-justification from absolute affection;

2. as practical reason, i.e. as a willing toward/ of a whole life led by reason, as formative freedom, creative power, renewal.

Axiological reason as the third form of reason has rather been eclipsed, or even trumped by absolute affection, which takes over in the final decision on the evaluation and the ranking of goods. What does this absolute affection have in common with reason at all? Husserl precisely calls this personal, affective moment in various passages simply 'irrational'. Does this already mean 'unreasonable' (unvernünftig)?

Certainly, the FPR in an affective interpretation suffers the loss of some of points that are upheld by Kant as reasonable/rational characteristics: in the first place one could name autonomy; equally to this, the loss of guaranteed validity that the universal - which is purified of all empirical traces - should warrant. According to Husserl's conception and understanding of reason, absolute affection cannot be subsumed under the rational position character (Vernunfthesischarakter) either, as it does not correspond to the legitimized positing of a fulfilled intuition (but rather belongs to the passive sphere). It rather seems as if absolute affection posits me as a person, rather than me positing it as a rational character (Vernunftcharakter).

Having said that, there are also, by all means, aspects in which the FPR in affective interpretation maintains its reasonable/rational character (Vernunftcharakter):

1. in the commanding and imperative, i. e. in the genuine and originary experience of an ought (sic volo, sic iubeo);

2. in the transcendence of mere inclinations; partly even in the pulling or tearing oneself away form these immediate inclinations for the sake of following the call of the absolute ought;

3. in the sort of direct, inscrutable and unfathomable givenness that cannot be deduced further (herausvernünfteln);

4. in the givenness of an absolute call which is accompanied by the feelings of respect (awe) and love - and:

5. - despite the heteronomy in the mode of givenness: in the enabling of a free will (good will) which stretches out over a whole life.

Against Husserl's own thesis, which regards the absolute ought as simply 'irrational' without any component of reason, one could argue that this could be seen differently: namely if one is willing to interpret the source of practical reason as the law of the heart, which naturally has an affective quality. Because through this, the I as a person becomes autonomous in relation to its mere wants, even if this occurs through a deeply, heteronomously felt, affective ground. That reason (Vernunft) in its givenness has this very affective and existential component already 
shows up in Kant, if he is read with a phenomenological emphasis.

But if Husserl, on the one hand succeeds in finding the adequate philosophical expression for the affective aspect, he repeats, on the other, the Kantian figure of the 'irrationality of subjective affectivity' on a higher level. Because for Husserl only 'rational faith' (Vernunftglaube) can warrant a universal compatibility of the singular absolute oughts and only through that do they obtain their 'ultimate sense' (letzter Sinn) - according to Husserl (cf. Melle 2005b: 137-138). In 'rational faith', reason again only comes into play as rationality (and theoretical reason), which is supposed to solve the dichotomy between personal/irrational and universal/ rational.

However, one can also find a different thread in Husserl's considerations that deals in a more integrative way with this area of conflict: in the transformation of the foundation of science (Wissenschaft) and in the practice of intersubjective justification and verification.

"Autonome Wissenschaft ist das Organ der Menschheit, in ihrem Streben zu einem praktisch vernünftigen, die ,Glückseligkeit' verbürgenden Leben [...]. Demgegenüber die Tendenz, dem ,Irrationalen' genugzutun und die religiösen Irrationalitäten oder die Irrationalitäten der Persönlichkeit - das spezifisch Ethische, das absolute, sich an die Individuen ganz persönlich richtende Sollen - als Erkenntnisgrund zu verwerten und damit statt autonomer Wissenschaft Wissenschaft zu fördern, die dem Rationalen genugtut, eventuell der Wissenschaft selbst mit all ihrer verbleibenden Rationalität ein irrationales - aber doch ein einsichtig gegebenes - Fundament zu geben" (Husserl, Ms. A V 21: 126a).

One 'irrational' aspect, according to Husserl, which is given in a comprehensible (einsichtig) manner, which - in any case - is not 'pathological', is the facticity of the ethical as a personal experience. This personal facticity, however, always occurs in an equally factual community. Hence, it neither eludes intersubjective and institutional justification nor does it, just as little, forget its absolute endowment beyond rationally erected institutions. The FPR as both affective and formal facticity thus founds/institutes the modes of justifying, judging and testifying (bezeugen) as an intersubjective practice.

This proves itself in the claim that I have to answer and be answerable for my absolute ought, which I can never be absolutely sure of:

"Ich sehe ein, dass meine Pflicht als zum Faktum meiner subjektiven Lage, subjektiven Vorbereitung gehörige und meine Pflicht als Idee einer unbekannten,wahren' Pflicht eine peinliche Differenz ausmachen. Ich muss meiner vermeintlichen Pflicht folgen, das jedenfalls ist absolut wahre Pflicht im Jetzt; aber was ich in meinem Handeln soll, das ist die wahre Pflicht, deren ich nie völlig gewiss sein kann“ (Husserl, Ms. A V 21: $14 \mathrm{~b})$.

And, further: "Aber wenn das Gewissen spricht, mich anruft, ist nicht mein Leben enthüllt und ich rechne nicht aus, was da an dieser Stelle das Beste ist. Freilich, jetzt kann ich in peinlicher Wahl sein." (Husserl, Ms. A V 21: 84a) --- "Jetzt ist die Stunde, der Augenblick, jetzt ,muss' ich mich entscheiden, entscheide ich mich überhaupt nicht, so verletze ich schon ein absolutes Sollen. Ich muss als freier. Aber jetzt kann ich nicht mehr meine 'Lage' ändern. [...] Jetzt ,kann' ich mich nur für das absolute Sollen entscheiden, wie es eben im Jetzt spricht“ (Husserl, Ms. A V 21:14a).

What Husserl makes explicit here is the existential separation that hits me, if reason alone cannot solve the conflict of values and responsibilities anymore; consequently, Husserl expresses the burden of the decision of willing, which, in all its freedom, is not arbitrary but responsible and, by that, follows a call. Husserl underlines the passivity which makes the free will become a responsible (free) will. Thereby, 
the decision which the subject has come to, does not cast it out of society/community (like so often in the figure of Selbstsein in more existential approaches), but calls even more strongly on the subject to justify and testify for the facticity of its personal ethical ought.

How is the subject supposed to manage this, if we stand, according to Husserl, "in einer Relativität mit relativen Evidenzen? [...] in der Endlosigkeit der intersubjektiv-historischen Zusammenhänge?" (Husserl, Ms. A V 21: 84a).

It now seems clear to Husserl that the being of the ought (Sein des Gesollten) can principally not be given in an evidence of selfgivenness of that being: "[E]vident im Sinne der Selbstgebung wäre nur das reine absolute Sollen 'selbst' [...]. Die Evidenz trägt aber in sich die Evidenz, dass hier geurteilt werden muss, was selbst nicht evident ist und nie werden kann" (Husserl, Ms. A V 21: 10b).

Thus, the act of judging is demanded in a non-evident and absolute singular case. Husserl talks about "Nachmessen nicht nach einer allgemeinen Regel, als einem allgemeinen Satz, sondern nach einem in jedem Einzelfall bestimmten und in anderer Weise allgemeinen Maß" (Husserl, Ms. A VI 30:174).

This description carries the features of the reflective judgment that is given in singular events and yet has to find the universal rule for it. As Kant describes it in the Critique of Judgment, there is no pure evidence at hand, but I have to impute (ansinnen) this judgment to others - in ethical terms, by testifying and responding to it (in contrast to the merely aesthetic judgment).

Hence, the FPR in an affective, phenomenological interpretation does not have to rely exclusively on rational faith. It rather opens up a specific form of judgment and justification, which is not exclusively based on a rationalist principle of evidence but enfolds as communication in an intersubjective space.

\section{References}

Drummond, J. J. 2005. "Moral objectivity: Husserl's sentiments of the understanding", in Edmund Husserl. Critical Assessments of Leading Philosophers. Vol. V. Ed. by D. Welton and G. Zavota. London/ New York: Routledge, 80-98.

Crowell, S. 2005. "Phenomenology, value theory, and nihilism", in Edmund Husserl. Critical Assessments of Leading Philosophers. Vol. V. Ed. by D. Welton and G. Zavota. London/New York: Routledge, 99-118.

Husserl, E. 1952. Ideen zu einer reinen Phänomenologie und phänomenologischen Philosophie. Zweites Buch. Ed. by M. Biemel. Den Haag: Nijhoff. (= Hua IV).

Husserl, E. 1987. Aufsätze und Vorträge (19221937). Ed. by T. Nenon \& H. R. Sepp. Dordrecht: Kluwer. (= Hua XXVII).

Husserl, E. 1988. Vorlesungen über Ethik und Wertlehre (1908-1914). Ed. by U. Melle. Dordrecht: Kluwer. (= Hua XXVIII).

Husserl, E. 1985. Erfahrung und Urteil. Ed. by L. Landgrebe. Hamburg: Meiner. (= EU).

Husserl, E. Quoted unpublished manuscripts: A V 21, A VI 30, B I 21.

Kant, I. 1974. Kritik der praktischen Vernunft. Grundlegung zur Metaphysik der Sitten. Werkausgabe VII. Ed. by W. Weischedel. Frankfurt a. M.: Suhrkamp. (= KpV) (= Grundlegung).

Loidolt, S. 2009. Anspruch und Rechtfertigung. Eine Theorie des rechtlichen Denken im Anschluss an die Phänomenologie Edmund Husserls. Dordrecht: Springer.

Melle, U. 1998. “Einleitung des Herausgebers”, in Husserl 1998, XIII-XLIX.

Melle, U. 2004. "Husserls personalistische Ethik", in Fenomenologia della ragion pratica. Ed. by B. Centi and G. Gigliotti. Napoli: Bibliopolis, 327-356.

Melle, U. 2005a. "Husserl's phenomenology of the willing", in Edmund Husserl. Critical Assessments of Leading Philosophers. Vol. V. Ed. by D. Welton and G. Zavota. London/New York: Routledge, 61-79. 
Melle, U. 2005b. "Edmund Husserl: from reason to love", in Edmund Husserl. Critical Assessments of Leading Philosophers. Vol. V. Ed. by D. Welton and G. Zavota. London/New York: Routledge, 119-139.

Rawls, J. 1993. “Themes in Kant's Moral Philosophy”, in Kant \& Political Philosophy. The Contempo- rary Legacy. Ed. by R. Beiner and W. J. Booth. New Haven \& London: Yale University Press, 291-319.

Schuhmann, K. 1991. "Probleme der Husserlschen Wertlehre”, Philosophisches Jahrbuch 98: 106-113.

\section{HUSSERLIS IR PRAKTINIO PROTO FAKTAS - FENOMENOLOGINÉS PRETENZIJOS İ FILOSOFINĘ ETIKĄ}

\section{Sophie Loidolt}

Teigiama, kad savo vèlyvojoje etikoje Husserlis reinterpretuoja toki filosofini turini, kuris geriausiai gali büti suprastas kantiškosios "praktinio proto fakto" sampratos šviesoje. Nuo pat 1917-1918 metu Husserlis vis mažiau demesio skyrè pirminei mokslinès etikos idejai igyvendinti. To priežastis glüdi Gemütsakte analizeje, po kurios net keli pagrindiniai praktinio proto fakto teorijos bruožai pamažu įsismelke i Husserlio mąstymą: tai asmeninis rüpestis (prievolè) ir praktikos pirmumo iškélimas, einantis kartu su universalaus pagristumo siekiu.

Husserlis pripažista, kad etinis faktiškumas negali būti deramai suvoktas mokslo, paremto įrodymais, kalbančio objektyviai ir be-asmeniškai apie troškimų, vertinimo ar pasirinkimo aktus. Todèl Husserlis pereina prie praktinio proto fakto kaip naujo filosofinio jo etikos branduolio reinterpretacijos, kartu pereidamas prie asmenines, afektyvumu apibūdinamos etikos. Kitaip nei anksčiau, Husserlis traktuoja praktinio proto fakta ne kaip akivaizdžius materialaus Gemüt priorinius desnius. Asmenyje ir jo etineje patirtyje kaip absoliučioje afekcijoje Husserlis aptinka kažka per se neobjektyvuojama ir racionaliai neparodoma. Taip Husserlis užčiuopia ir fenomenologiškai paaiškina ne-objektyvuojama privalejimo šaltinį ir galimybę jo laikytis.

Reikšminiai žodžiai: fenomenologija, Husserlis, Kantas, etika, praktinis protas.

Iteikta 2009-03-25; priimta 2009-06-11 